Luxembourg Income Study Working Paper No. 285

Single MOtherhoOd, Employment, oR SOCIAL Assistance: Why ARE U.S. WOMEN POORER than WOMEN IN OTHER

Affluent Nations?

Karen Christopher

November 2001 
Single Motherhood, Employment, or Social Assistance: Why Are U.S. Women Poorer Than Women in Other Affluent Nations?

\title{
Karen Christopher*
}

\begin{abstract}
U.S. women have higher poverty rates than women in other affluent nations. In this paper I attempt to explain this disparity by examining the effect of single motherhood, employment, and social assistance on women's poverty. With cross-national comparisons of quantitative data, I find that the relatively high rate of single motherhood among U.S. women is not a main cause of their high poverty rates. Compared to their counterparts in other Western nations, U.S. women, mothers and single mothers are among the most likely to earn poverty wages. In addition, U.S. social assistance programs are the least effective in reducing poverty. I conclude with the policy implications of my findings, focusing on strategies to ameliorate the high poverty rates of U.S. women and mothers.
\end{abstract}

Keywords: poverty, gender, social policy, employment, single parenthood

*Karen Christopher is Assistant Professor of Sociology and a member of the Women's Studies teaching faculty at the University of Pittsburgh. Direct correspondence to Karen Christopher, 2J22 Posvar Hall, University of Pittsburgh, Pittsburgh PA, 15260 (kchristo@pitt.edu). The author thanks Paula England, Lisa Brush, John Markoff, Avery Kolers, and three anonymous reviewers for their insightful comments. 
Single Motherhood, Employment, or Social Assistance: Why Are U.S. Women Poorer Than Women in Other Affluent Nations?

Despite its reputation as the richest country in the world, in the U.S. women are more likely to live in poverty than women in other affluent nations. Because women primarily receive income from their families, the labor market and the welfare state, below I use cross-national, quantitative data to assess how women's participation in these institutions affects their poverty status in the U.S. and eight other Western nations (Australia, Canada, Finland, France, Germany, the Netherlands, Sweden, and U.K.). The main question I address is why U.S. women's and mothers' poverty rates are higher than those of their Western counterparts.

I begin with the theoretical framework and past research that inform my research questions. Then I describe the data and methods I use to analyze women's poverty in the U.S. and eight other Western nations. Logistic regression decomposition analyses and calculations of poverty rates based on different measures of income assess how family status, market income, and social assistance payments affect poverty. I conclude by discussing policies that could reduce the high rates of poverty of U.S. women, mothers, and their children.

The Family, Market, State and Women's Poverty: Theory and Past Research When considering how the family, market and state affect women's and mothers' economic outcomes, it is crucial to consider the intersections among these three institutions. ${ }^{1}$ Below I discuss each in turn, focusing on how these institutions interact to benefit or disadvantage women.

Women's family status, particularly their marital and parental status, unquestionably affects their economic well-being. Regardless of marital status, women who are mothers fare worse economically than female non-mothers (Folbre, 1987). To be sure, married and cohabiting women benefit from the wages of a partner, while most single women do not. Yet due to increases in women's economic status in recent decades, single non-elderly women without children can often form non-poor households 
independent of men. Parenthood, however, continues to lower women's earnings (Budig and England, 2001; Folbre, 1987, 1994; Waldfogel, 1997). ${ }^{2}$ Women typically perform more caregiving work in the home than their male partners (O'Connor, 1996). Because they spend more time taking care of children and/or elderly relatives than men, women often reduce their hours of paid work, which lowers their incomes and reduces their pension payments later in life (Folbre, 1987). Mothers also may be less productive on the job, given the demands of childrearing, and they may face employer discrimination because they have children (Budig and England, 2001).

Caregiving demands are typically more burdensome for single mothers, many of whom are sole earners and caregivers for their families and thus "time poor". Many single mothers are also financially poor, given that many work part-time due to caregiving demands, and in some countries, many single mothers lack income support from male partners. ${ }^{3}$ Increases in divorce and out-of-wedlock childbearing made single motherhood increasingly common in the 1980s and 1990s (McLanahan and Kelly, 1999). Given the lack of subsidized childcare and paid leave policies in the English-speaking countriesparticularly the U.S.- - low-income single mothers with young children are especially hard-pressed to afford childcare and remain attached to the labor market. All of these factors suggest that it is not gender per se, but motherhood that elevates women's poverty rates (see Folbre, 1987).

Research suggests that single motherhood continues to be a primary cause of U.S. women's persistently high poverty rates (McLanahan et al., 1989; McLanahan and Kelly, 1999). As discussed below, U.S. women have higher rates of single motherhood than women in other Western nations (when those in cohabiting couples are not considered single) (Christopher et al., 2001). In almost all Western countries, single mothers have higher poverty rates than other citizens, though welfare states in most countries substantially reduce single mothers' poverty rates (McFate et al., 1995). ${ }^{4}$

Labor markets and welfare states are other important sources of income. Regarding the former, we must consider women's labor force participation rates, their hours of employment and their wages. All three of these factors determine their market income. Like their Western counterparts, U.S. women's 
labor force participation rates, hours of employment, and wages have generally increased over the past few decades (though a considerable sex gap in pay remains) (Bernhardt et al., 1995; Gornick, 1999; Reskin and Padavic, 1994). These trends by themselves should reduce poverty rates among women.

But gender inequalities in labor markets persist. As stated above, women's caregiving responsibilities reduce their employment hours and pay. Further, jobs filled primarily by men pay higher wages than jobs filled primarily by women, even when these jobs are comparable on a number of characteristics (England, 1992). Many typically "female" jobs are service sector jobs with low pay and little, if any, room for advancement (Reskin and Padavic, 1994). Across Western countries, women work in low-wage jobs. Kilkey and Bradshaw (1999) find that about 30-40\% of Canadian and U.S. employed single mothers live in poverty despite their earnings, while about $20 \%$ of Australian employed single mothers are in poverty. ${ }^{5}$

U.S. women are in need of wages that pay above the poverty line, because they live in a highly "liberal" welfare state ${ }^{6}$ in which social transfer payments for single mothers pay well below the poverty line (Blank, 1997). In terms of the generosity of social transfers for single mothers and the availability of state services (i.e. childcare and paid leave) for working women, the U.S. lags behind other "liberal" welfare states (Australia, Canada, and the U.K.) (Meyers et al., forthcoming; O'Connor et al., 1999). While women in "liberal" welfare states have benefited from employment policies, these policies are based on the notion of gender sameness - that female workers should be like male workers-in the context of welfare states that are not attuned to the needs of working women (O'Connor et al., 1999).

In other Western countries, welfare states use two main strategies to reduce poverty among nonelderly mothers: social transfers for caregivers of young children, or social transfers combined with state supports for women's labor force participation (McFate et al., 1995; Sainsbury, 1996). Lewis (1992) and Sainsbury $(1994,1996)$ discuss the "male breadwinner" (and female caretaker) model of social policymost evident in the Netherlands and Germany_in which mothers with young children often eschew paid work. $^{7}$ In the Netherlands, single mothers receive generous social transfers and have low rates of labor 
force participation. In Germany social transfers are also generous, though more single mothers engage in paid work (Kilkey and Bradshaw, 1999).

In contrast, the French and Scandinavian welfare states are based on the "individual" model of social policy—similar to the "parent-worker" model discussed by some social scientists (Lewis and Hobson, 1997; Sainsbury, 1996). In these nations mothers, like all citizens, receive social transfers, and the state provides employment services like subsidized childcare and paid leave that serve as incentives for paid work (Gornick et al., 1998; Sainsbury, 1996). Many social scientists praise the "individual" or "parent-worker" welfare states, as they increase labor force participation among mothers, and substantially reduce poverty among women and mothers (McFate et al., 1995; Meyers et al., forthcoming).

Some past research has considered how the family, market and state affect sex gaps in poverty. Casper et al. (1994) find that Western nations generally use one of three strategies to keep sex gaps in poverty low: high levels of social transfers (the Netherlands), high levels of female labor force participation (Sweden) or high rates of marriage (Italy). ${ }^{8}$ With more direct measures of the effects of the labor market and social transfers on women's poverty, Christopher et al. (2001) find that the U.S. welfare state, along with those of Australia, Canada, France and Germany, do very little to reduce sex gaps in poverty. With simulations of poverty rates based on the market incomes of women and men, they find that U.S. wage inequality exacerbates the sex gap in poverty, though gender inequality in market income in other countries (Australia, France, and the Netherlands) is more severe than in the U.S. Their findings also suggest that higher rates of single motherhood increase women's poverty in Western nations.

Thus, the literature reviewed above suggests that increases in single motherhood should increase women's poverty, increases in employment—provided jobs pay well—should decrease women's poverty, and some welfare states significantly reduce women's poverty through social assistance programs and/or employment supports that increase their earnings.

\section{Research Questions}


To this literature, I add a focus on the poverty rates of mothers and single mothers, because the literature reviewed above suggests that it is not gender per se, but motherhood that lowers women's economic status. I also provide a more precise comparative analysis of how single motherhood affects the high poverty rate of U.S. women, more detailed measures of how different kinds of labor force participation affect poverty rates, and analyses using recent data for nine Western countries. In addition, my results have timely policy implications given the recent U.S. welfare reform and its pending reauthorization. While I discuss men's relationship to the family, market and state, I focus on how these institutions contribute to the comparatively high poverty rates of U.S. women and mothers.

I begin by presenting the poverty rates of women, mothers, single mothers, and men. Next I ask to what extent the higher prevalence of single motherhood increases poverty among U.S. women. I go on to look at U.S. employed mothers' poverty rates and then discuss the extent to which social assistance programs reduce poverty rates. Before presenting my results, I discuss the data and methods I use in my analyses.

\section{Data, Measures, and Methods}

Data

To address these issues, I use the Luxembourg Income Study (LIS). The LIS is a consortium of data sets that includes surveys from 25 industrialized countries. It provides comprehensive information on household income sources. All data sets include nationally representative samples of the population in each country. My sample includes: Australia (1994), Canada (1994), Finland (1995), France (1994), Germany (1994), the Netherlands (1994), Sweden (1995), the United Kingdom (1995), and the United States (1994). I select these countries because they have complete information on marital and parental status, employment, and social transfers and taxes.

In order to generalize my results to those who are not likely to be in school or retired, my analyses include adults age 25-60. I refer to "parents" as those who live with children age 18 or under. If women or men have older children or children not living in their household, they are not considered 
"parents". In the analyses below I include only women and men who are heads of households or their partners (spouses or cohabiting partners); I always count single mothers as heads of households. ${ }^{9}$ Regarding marital status, those who are married or cohabiting are considered non-single; "single" refers to those who are never married, divorced, or widowed. ${ }^{10}$

\section{Measures}

I use poverty as an economic indicator. With this measure I assume that money income is the central resource used to obtain goods and services, and hence many kinds of social participation. Of course there are important resources that money cannot buy, such as safety, health, or large social networks; money is not the only determinant of well-being. But because money is so liquid, it is a very important determinant of a person's life chances. Moreover, equal participation in society is perhaps more important for women, who historically have not been granted equal citizenship with men (see O'Connor, 1993). Thus, poverty is an especially important indicator with respect to women's economic outcomes.

The measure of poverty I use here concerns whether families have adequate material resources relative to others in their nation. In most measures below, poverty is measured by having a disposable family income of less than $50 \%$ of the median income of one's country. ${ }^{11}$ Disposable income is after-tax income and includes any social transfers or tax credits a family receives. In one analysis I measure poverty by one's own market income rather than one's disposable family income.

Like the U.S. poverty line, I adjust household income for the number of persons living in the household. To do this, I use an equivalence scale. Equivalence scales are widely used to determine what level of income a family of one size needs to attain the same standard of living as different-sized families. In the analyses below, I divide family income by a commonly used equivalence scale, the square root of family size. (See the Appendix for details on my choice of equivalence scale.)

\section{Methods}

I use several different methods to analyze data: logistic regression analyses and regression 
decomposition techniques to assess how family status affects poverty; the calculation of employment rates and poverty rates based on one's own market income to assess how employment affects poverty; and the comparison of poverty rates before and after social transfers and taxes are included in income to assess how social assistance programs affect poverty. Regarding the former, because the dependent variable in my analyses (poverty) is dichotomous, the logistic distribution is the appropriate functional form. I run a logistic regression analysis for U.S. women. I report the results of this analysis, along with U.S. women's means on these variables, in Appendix Table 1. I use a regression decomposition technique to simulate U.S. women's hypothetical poverty rates if they had the same rates of single motherhood as women in other nations. (Recall that U.S. women have the highest rate of single motherhood.) The regression decomposition technique first uses U.S. women's means and the coefficients from their logistic regression equations of poverty to predict U.S. women's actual poverty rate. Then, I substitute the rate of single motherhood found in the other eight nations for that of the U.S. rate (one nation at a time), keeping the means and the coefficients for all other variables the same. The hypothetical poverty rates that result indicate what U.S. women's poverty rates would be if they had the rate of single motherhood found in the other eight nations. In Table 2, I show the extent to which U.S. women's hypothetical poverty rates are lower than their actual poverty rates.

The methods used to examine labor force participation rates and poverty rates according to employment status are straightforward calculations of means, described in greater detail below. I also consider how social assistance programs affect poverty rates. Social assistance programs include any social transfer payments received by families, means-tested or non-means-tested: unemployment compensation, child or family allowances, sick pay, disability pay, maternity pay, and near-cash benefits like food stamps and housing benefits. Taxes must also be included as social assistance, because in many countries the tax system redistributes income with tax credits to families (like the Earned Income Tax Credit in the U.S.). Social retirement benefits are also considered social transfers, though few people in this sample receive them due to the age cutoff of 60 . The analyses concerning the effects of social 
assistance programs on poverty rates compare poverty rates based on two different measures of income: pre-tax, pre-transfer income and post-tax, post-transfer (or disposable) income. The difference between these two poverty rates shows the extent to which social assistance programs (or social transfers and tax credits) reduce poverty.

\section{Results}

As seen in Table 1, women living in the Anglo-Saxon countries and Germany have poverty rates above $10 \%$, and U.S. women have the highest rate (15\%). Dutch and French women have more moderate rates (6-7\%), and Finnish and Swedish women have the lowest rates (below 3\%). The same trends hold for mothers, though in most countries their poverty rates are slightly higher than all women's. The exceptions are Finland and Sweden, where mothers' poverty rates are the same as or lower than those of all women. U.S. mothers are the most impoverished; nearly one out of five U.S. mothers lives in poverty. (Table 1 about here)

In all countries, the poverty rates of single mothers are higher than those of all women or of mothers. Single mothers are the most impoverished in the U.S., where $45 \%$ of them live in poverty. In Germany, Canada, Australia, and the U.K., $32-41 \%$ of single mothers live in poverty. French single mothers have a more moderate poverty rate (13\%), and Finnish and Swedish single mothers have low poverty rates (around 5\%). As regards men's poverty, “Anglo-Saxon" and German men have the highest rates, Finnish and Swedish men the lowest. In all nations except the latter two, men's poverty rates are lower than women's.

In order to assess the causes of U.S. women's and mothers' high poverty rates, I first examine single motherhood (recall that this includes never married, divorced, or widowed women). From analyses not presented here, I find that the proportion of all U.S. women who are single mothers is $14 \%$, which is higher than all other nations. In other countries, slightly lower percentages of women are single mothers- $13 \%$ in France, $10 \%$ in Sweden and U.K.- and around 5-8\% in the other nations. As stated above, single mothers have higher poverty rates than other family types; so, to what extent does the high 
rate of single motherhood increase poverty among U.S. women?

(Table 2 about here)

Table 2 shows the percentage by which U.S. women's poverty rates would decrease if they had the lower rate of single motherhood found in the eight other nations. As stated above, regression decomposition analyses use the U.S. women's logistic regression equation and means (presented in Appendix Table 1) to predict U.S. women's actual poverty rate. Then I substitute the rates of single motherhood of the women in the eight other nations (one nation at a time) into the U.S. equation and simulate U.S. women's hypothetical poverty rates. Table 2 shows the percentage by which these hypothetical poverty rates are lower than U.S. women's actual poverty rate. We see that women in the four countries with the lowest rates of single motherhood-Australia, Finland, Germany, and the Netherlands - have rates of single motherhood that would reduce the U.S. women's poverty rate by 11 $15 \%$, or by about 2 percentage points. Having the lower rate of single motherhood of Canadian mothers would reduce U.S. women's poverty by $11 \%$, or by about 1.5 percentage points. Having the Swedish, U.K., and French rates of single motherhood would only slightly reduce U.S. women's poverty rate. The main finding from Table 2, then, is that lowering the prevalence of U.S. single motherhood to equal its prevalence in other Western countries would not reduce U.S. women's poverty by a substantial amount. That is, even when having the lower rates of single motherhood of their Western counterparts, U.S. women's poverty rates remain quite high.

Thus, we must look to other sources to explain U.S. women's high poverty rate: the labor market and the welfare state. Regarding the former, in Table 3 I present the employment rates (full- or parttime) and full-time employment rates (35 hours or more per week) for mothers, single mothers, women and men. U.S. mothers have relatively high rates of employment, lower only than Finland and Sweden, and they have the highest rates of full-time employment (along with Canadian mothers). A similar pattern results with respect to single mothers. Though U.S. single mothers' employment rates fall behind those of Scandinavian and French single mothers, U.S. single mothers have the highest full-time 
employment rates $(60 \%) .{ }^{12}$ In contrast, Dutch and U.K. single mothers have quite low employment rates, particularly for full-time employment.

(Table 3 about here)

Table 3 shows that the comparatively high poverty rates among U.S. women, mothers and single mothers are not due to low employment rates or high rates of part-time employment. In fact, U.S. women, mothers and single mothers have relatively high employment rates and among the highest fulltime employment rates when compared to women in other countries.

Yet high employment rates will not ameliorate poverty if jobs do not pay well. Table 4 addresses the crucial issue of the extent to which earnings pull people out of poverty. Note that these poverty rates are based on the market income of each individual only, so do not include measures of other family income or any welfare state income. I calculate poverty rates this way to show whether or not an individual's job, or market income only, would pull his or her family out of poverty. ${ }^{13}$ In other words, these analyses show the extent to which jobs pay poverty wages.

(Table 4 about here)

Regarding mothers, we see that in all countries except Finland and Sweden, over 50\% of employed mothers earn poverty wages. As expected, mothers who work full-time are more likely to escape poverty with their own earnings. Canadian, U.S., and French mothers who work full-time have the highest market income poverty rates, around 42-48\%, while U.K. and Swedish mothers who work full-time have the lowest market income poverty rates, around $17-28 \%$. We see a similar pattern among single mothers, who when employed either full- or part-time, have market income poverty rates hovering around 50-60\% in the U.K. and France. Only a third of single mothers in Finland and Sweden earn poverty wages. U.S. single mothers who are employed full-time are the most likely to earn poverty wages, followed by French, Canadian, and Dutch single mothers. Overall, U.S. mothers and single mothers who are employed full-time have earnings that would leave a comparatively high percentage of them in poverty. 
Among all women, we see that about one-third to one-half of employed women in all countries earn poverty wages. Fewer women are in market income poverty when they work full-time. Dutch, U.K., and Swedish women are quite likely to escape market income poverty when they work full-time, though in the former two countries, women's full-time employment rates are quite low. It is also interesting to note that U.S. women who work full-time have market income poverty rates that are over 10 percentage points lower than those of U.S. mothers who work full-time. In all countries, the majority of men who are employed full- or part-time earn above-poverty wages; fewer than $25 \%$ of men who work full-time earn poverty wages. Generally, men's employment prevents poverty to a greater extent than women's; this is certainly true in the U.S.

Thus, compared to their Western counterparts, U.S. mothers and women who work full-time are among the least likely to hold jobs that pull them out of poverty. Thus, it is not the lower prevalence of paid work, but lower wages that increase U.S. mothers' and women's poverty rates vis-à-vis their Western counterparts. In all other countries (except Canada), full-time employment is more likely to pay above-poverty wages.

(Table 5 about here)

Lastly, the welfare state is an important source of income for mothers in some countries. Women and mothers who live in generous welfare states may have low poverty rates regardless of labor force participation. Table 5 examines the extent to which social transfers and taxes reduce poverty among different groups. As stated above, this table shows the difference between poverty rates based on pretax/transfer income and those based on post-tax/transfer income-or the extent to which social transfer and tax systems reduce poverty rates. Regarding mothers, we see that transfers and taxes in Sweden, Finland, and France are the most effective in reducing mothers' poverty rates. "Anglo-Saxon" countries (except for the U.S.) reduce poverty more moderately with taxes and transfers, and Germany and the U.S. reduce mothers' poverty the least, by $29 \%$ and $13 \%$ respectively. A similar pattern holds for single mothers. The Swedish and Finnish tax and transfers systems reduce poverty the most (by over 80\%), and 
the Dutch and French tax and transfer systems are quite effective in reducing single mothers' poverty rates. Again the German and U.S. tax and transfer systems are the least effective in reducing single mothers' poverty. Similar patterns emerge when we consider the effectiveness of social transfer and tax programs in reducing women's and men's poverty rates; the U.S. social transfer and tax system is by far the least effective in reducing poverty.

(Table 6 about here)

Table 6 summarizes the findings of Tables 4 and 5, showing how different states reduce mothers' and single mothers' poverty, with respect to full-time employment and their social transfer and tax systems. The U.S. is an outlier, because compared to other nations, full-time employment and the social transfer and tax system are generally the least effective in reducing mothers' and single mothers' poverty rates. Compared to the U.S., in Canada full-time employment is less effective in reducing mothers' poverty, but is more effective in reducing single mothers' poverty. Canada has a slightly more effective social transfer and tax system, and that of France is much more effective; but none of these three countries substantially reduces mothers' poverty through full-time employment. In Australia, the Netherlands, and Germany, full-time employment and social assistance moderately reduce poverty. The same is true in the U.K., though full-time employment there is more effective in reducing mothers' poverty (but recall that low proportions of U.K. mothers and single mothers work full-time). Mothers and single mothers in Sweden and Finland benefit the most from employment and social transfers/taxes—both quite effectively lower poverty rates.

Thus, with respect to different kinds of welfare states, we see that the "individual" or "parentworker" welfare states are the most effective in reducing poverty via employment and social assistance. The exception is France, often considered a "parent-worker" welfare state with its substantial provision of subsidized child care and paid leaves; here full-time employment often pays poverty wages to mothers and single mothers. The "Anglo-Saxon" countries (with the exception of the U.S.) reduce poverty moderately with social transfers, but they differ on whether full-time employment pays above-poverty 
wages - this occurs to a greater extent in the U.K. The "male breadwinner" welfare states are those in which both full-time employment and the social transfer/tax system moderately reduce mothers' poverty. This is somewhat surprising, as we might expect the social transfer and tax systems to be more effective in Germany and the Netherlands, where mothers and particularly single mothers have not been "pushed" into the labor market to the extent of mothers and single mothers elsewhere.

\section{Discussion}

Above I pinpoint three potential causes of U.S. women's high poverty rates: the comparatively high rate of single motherhood, the preponderance of jobs (even full-time jobs) that pay poverty wages, and the shortcomings of social assistance programs. Regarding single motherhood, I show that lowering the U.S. rates of single motherhood to equal those of their Western counterparts would only slightly reduce U.S. women's poverty (Table 2). U.S. women would still have the highest poverty rates if, for example, they had the low rate of single motherhood found in the Netherlands. While single motherhood may have detrimental effects on families (McLanahan and Sandefur, 1996), it is not the primary cause of U.S. women's comparatively high poverty rates. Thus, efforts to reduce U.S. women's poverty should not call for increased marriage among low-income women-a current focus of some conservative politicians. Strategies that promote increases in marriage also ignore the fact that for various valid reasons, some women choose to avoid marriage. Instead of focusing on single motherhood, efforts to reduce U.S. women's poverty should confront gender inequalities in the labor market and the shortcomings of U.S. social assistance programs.

Generally, it is not low employment rates, but the preponderance of poverty-wage jobs that exacerbates U.S. women's poverty. Compared to their Western counterparts, U.S. women, mothers and single mothers who work full-time are among the least likely to work in jobs the pay wages above the poverty line (Table 4). And U.S. men do not share U.S. women's concentration in poverty-wage jobs. This suggests that in lower-tier jobs, gender inequality in wages remains a serious problem. Because women are over-represented in caregiving and other service sector jobs that often pay low wages, federal 
increases in the minimum wage and local "living wage" ordinances could ameliorate poverty among working women. Increased unionization of typically female jobs in the service sector could also bolster women's wages. In addition, education and job training programs that encourage women's entrance into traditionally male occupations could decrease women's poverty rates. Yet more fundamental changes to the U.S. labor market may be necessary to combat gender inequality. For example, comparable worth policies promote structural change in a U.S. labor market that continues to pay higher wages to "male jobs" than comparable "female jobs". In sum, my results suggest that any attempts to reduce U.S. women's high poverty rates must deal with the substantial numbers of them that earn poverty wages. The stinginess of the U.S. welfare state is not surprising. As typically found in cross-national research, U.S. social assistance programs are the least effective in pulling citizens out of poverty (Table 5). Here I find that nations that have generous social assistance programs in addition to employment supports (or the "individual” or "parent-worker" welfare states) most effectively reduce mothers' and single poverty rates. Given the current political climate, increases in U.S. social assistance programs do not look likely. Yet, the current stress on employment among welfare recipients has the potential to create a window of opportunity for employment support programs like subsidized childcare, comprehensive job training programs, and transportation subsidies. Given that U.S. custodial mothers and single mothers are more likely than non-mothers to work in jobs that pay below the poverty line, employment policies targeted towards mothers are crucial in reducing gender inequality in labor markets.

In conclusion, a main cause of U.S. women's high poverty rates is that U.S. jobs often do not pay wages high enough to pull them and their families out of poverty. This is particularly troubling in a "liberal" welfare state that fosters market dependence. Further cutbacks in U.S. social assistance could be debilitating to women who cannot or do not work outside of the home and could deepen the poverty of those who remain in poverty despite being employed. For these reasons, and to document the effects of the recent welfare reform, further research on U.S. mothers' positions in the labor market and welfare state is crucial. 
Appendix

To adjust family income for household size, I use an equivalence scale that divides family income by the square root of family size. Cross-national research typically uses a parametric equivalence scale to adjust for family size. Research by Buhmann et al. (1988) suggests using a single parameter related to household size in the following equation: $E I=D / S^{e}$, where $E I$ is the equivalent income, $D$ is the family's disposable income, and $S$ is family size raised to the power of " $e$ ", the elasticity (Burkhauser et al. 1996). When $e$ is equal to 1 , no economies of scale exist, ignoring sharing among family members. In this case, equivalent income becomes per capita income. At the other extreme, when " $e$ " is equal to 0 , the differences in needs between large families and smaller ones are ignored, erroneously implying that a household of four, for example, can live as well on the same income as a family of one. Most international work chooses the midpoint between these two extremes, an " $e$ " between .50 to .55 , with .50 deemed the "International Experts scale" (Burkhauser et al. 1996). Because of this, I use an " $e$ ” of .50, which in turn divides disposable family income by the square root of family size. 


\section{References}

Berhhardt, A., Morris, M., \& Hancock, M.S. (1995). Women's gains or men's losses? A closer look at the shrinking gender gap in earnings. American Journal of Sociology, 101(2), 302-328.

Blank, Rebecca. (1997). It takes a nation: A new agenda for fighting poverty. Princeton, N.J.:

Princeton University Press.

Budig, M., \& England, P. (2001). The wage penalty for motherhood. American Sociological Review, 66(2), 204-225.

Buhmann, B., Rainwater, L., Schmaus, G., \& Smeeding, T. (1988). Equivalence scales, well-being, inequality, and poverty. Review of Income and Wealth, 34, 115-142.

Burkhauser, R.V., Smeeding, T., \& Merz, J. (1996). Relative inequality and poverty in Germany and the United States using alternative equivalence scales. Review of Income and Wealth, 42(4), 242-263.

Bussemaker, J., van Drenth, A., Knijn, T., \& Plantenga, J. (1997). Lone mothers in the Netherlands. In J. Lewis (Ed.), Lone Mothers in European welfare regimes (pp.96-120). London: Jessica Kingsley Publishers.

Casper, L.M., McLanahan, S., \& Garfinkel, I. (1994). The gender-poverty gap: What we can learn from other countries. American Sociological Review, 59, 594-605.

Christopher, K., England, P., Ross, K., Smeeding, T. \& McLanahan, S. (2001). The gender gap in poverty in modern nations: Single motherhood, the market and the state. Under publication review.

Christopher, K. (2001). Mothers' poverty in the U.S. over time: The effects of single parenthood and employment. Paper presented at the Institute for Women's Policy Research Conference, Washington D.C.

England, Paula. (1992). Comparable worth: Theories and evidence. New York: Aldine de Gruyter. Folbre, N. (1987). The pauperization of motherhood: Patriarchy and public policy in the United States. In N. Gerstel and H. Gross (Eds.), Families and Work (pp. 491-511). Philadelphia: Temple University Press. 
Forssen, K., \& Hakovirta, M. Work incentives in single parent families. Forthcoming in S. Ringen (Ed.), Poverty and security in the $21^{\text {st }}$ century. Aldershot: Aldgate.

Gornick, J.C. (1999). Gender equality in the labor market. In D. Sainsbury (Ed.), Gender and welfare state regimes (pp. 210-242). Oxford: Oxford University Press.

Gornick, J.C., Meyers, M.K., \& Ross, K.E. (1998). Public policies and the employment of mothers: A cross-national study. Social Science Quarterly, 79(1), 35-54.

Kilkey, M., \& Bradshaw, J. (1999). Lone mothers, economic well-being, and policies. In D. Sainsbury (Ed.), Gender and welfare state regimes (pp. 147-184). Oxford: Oxford University Press.

Lewis, J. (1992). Gender and the development of welfare regimes. Journal of European Social Policy, 2(3), 159-173.

Lewis, J., \& Hobson, B. (1997). Introduction. In J. Lewis (Ed.), Lone mothers in European welfare regimes (pp.1-20). London: Jessica Kingsley Publishers.

McFate, K., Smeeding, T., \& Rainwater, L. (1995). Markets and states: Poverty trends and transfer system effectiveness in the 1980s. In K. McFate, R. Lawson, and W.J. Wilson (Eds.) Poverty, inequality, and the future of social policy (pp. 29-66). New York: Russell Sage.

McLanahan, S., Sorensen, A., \& Watson, D. (1989). Sex differences in poverty, 1950-1980. Signs, $15,102-122$.

McLanahan, S., \& Kelly, E. (1999). Feminization of poverty: Past and present. In J. Chafetz (Ed.), Handbook of the sociology of gender (pp. 127-146). New York: Kluwer Academic Publishing.

McLanahan, S., \& Sandefur, G. (1996). Growing up with a single parent: What helps, what hurts. Cambridge, M.A.: Harvard University Press.

Meyers, M.K., Gornick, J.C., \& Ross, K.E. Gendering welfare state variation: Income transfers, employment supports, and family poverty. Forthcoming in N. Hirschmann and U. Liebert (Eds.), Reinventing the welfare sate? Feminist theory and comparative analyses of the U.S. and Europe. Rutgers, N.J.: Rutgers University Press. 
O'Connor, J.S. (1993). Gender, class and citizenship in the comparative analysis of welfare state regimes: theoretical and methodological issues. In G. Bock and S. James (Eds.), Beyond equality and difference: Citizenship, feminist politics, and female subjectivity (pp. 17-31). New York: Routledge.

O'Connor, J. S. (1996). From women in the welfare state to gendering welfare state regimes. Current Sociology, 44(2), 1-124.

O'Connor, J.S., Orloff, A.S., \& Shaver, S. (1999). States, markets, families: Gender, liberalism, and social policy in Australia, Canada, Great Britain, and the U.S. Cambridge: Cambridge University Press.

Reskin, B., \& Padavic, I. (1994). Women and men at work. Thousand Oaks, CA: Pine Forge Press.

Sainsbury, Diane. (1996). Gender, equality, and welfare states. Cambridge: Cambridge University Press.

Sainsbury, D. (1994). Introduction. In D. Sainsbury (Ed.) Gendering welfare states (pp.1-7). London: Sage Publications.

Scoon-Rogers, L., \& G.H. Lester. (1995). Child support for custodial mothers and fathers: 1991. Current population reports, Series P60(187). Washington: U.S. Bureau of the Census, Government Printing Office.

Spain, D. \& Bianchi, S.M. (1996). Balancing act: Motherhood, marriage and employment among American Women. New York: Russell Sage.

Waldfogel, J. (1997). The effects of children on women's wages. American Sociological Review, 62, 209-217. 


\section{Footnotes}

${ }^{1}$ A complete discussion of poverty in the U.S. would consider race and ethnicity. Due to a number of historical and structural inequalities, U.S. minorities, and particularly single mothers of color, continue to have poverty rates a great deal higher than those of whites. Regrettably, the comparative analyses below do not include race/ethnicity: the U.S. is too distinctive in these respects to allow meaningful comparisons with other Western nations. However, see Christopher (2001) for a discussion of how race and ethnicity affect mothers' poverty rates in the U.S. over time.

${ }^{2}$ Budig and England (2001) find that after controlling for a number of factors such as education, job experience and race/ethnicity, mothers face a wage penalty of $5 \%$ per child.

${ }^{3}$ While in many Western countries, the state pays child support when fathers do not, this is not true in the U.S. (See Christopher et al., (2001) for a discussion of child support policies across Western nations.) In the early 1990s, only 57\% of divorced U.S. mothers received any child support, and less than $35 \%$ of separated and never-married mothers received child support (Scoon-Rodgers and Lester, 1995, cited in Spain and Bianchi, 1996).

${ }^{4}$ For example, in the mid-1980s, the social transfer and tax system in the U.S. brought fewer than $5 \%$ of single mothers out of poverty; social transfers and taxes in the Netherlands and Sweden pulled over $75 \%$ of single mothers out of poverty, and those in Germany and France pulled about 34-53\% of single mothers out of poverty (McFate et al., 1995).

${ }^{5}$ In France, Germany, and the Netherlands, about $10 \%$ of employed single mothers are poor, while only about 5\% of employed Swedish and Finnish single mothers live in poverty (Kilkey and Bradshaw 1999). 6 "Liberal" welfare states are characterized by the market provision, rather than state provision, of income and services (such as childcare, and in the U.S. case, healthcare). Thus, in "liberal" states citizens are quite reliant on the market for their well-being.

${ }^{7}$ More recently, these nations begin to expect single mothers with young children to work for pay; for 
example, changes in Dutch social policy in the late 1990s encourage employment for Dutch single mothers (Bussemaker et al. 1997). But the data here are from the mid-1990s, so we should not see the effects of these changes in the analyses below.

${ }^{8}$ However, their findings regarding social transfers are speculative because they do not directly measure them in their analyses.

${ }^{9}$ I exclude adults living in households who are neither the head nor partner of the head, such as the livein parent of a married couple. These "other adults" could have a variety of effects on household income (i.e. they may contribute substantially or not at all), so it is unclear how one might measure their income. Because I exclude these other adults, only the person who identifies himself or herself as the head in gay and lesbian partnerships is included in my analyses. While I would prefer to include gay and lesbian cohabiting partners as married/cohabiting couples, only one country in my sample (the Netherlands) identifies gay and lesbian couples; all other countries report them as single individuals.

${ }^{10}$ I consider cohabiting couples as "married" here, thus assuming they share household resources. While this is not true for all cohabiting couples, I think it is a better assumption than the alternative- treating cohabiting couples as single individuals who do not share any resources.

${ }^{11}$ This is a relative measure of poverty rather than an absolute measure of poverty. In cross-national research a relative measure of poverty is often preferred, as it compares citizens in each country to each other, rather than creating an international (absolute) poverty line for several countries that may differ markedly in their provision of social services.

${ }^{12}$ Though other research suggests that Finnish women and single mothers have high rates of full-time employment (Forssen and Hakovirta, forthcoming).

${ }^{13}$ Like other measures of poverty presented above, these poverty rates use an equivalence scale to adjust for family size. 
Table 1: Poverty Rates ${ }^{\mathrm{a}}$ among Women, Mothers

$\underline{\text { Single Mothers, and Men }}$

\begin{tabular}{lrrrr}
\hline & \multicolumn{3}{c}{$\begin{array}{c}\text { Single } \\
\text { Momen }\end{array}$} \\
& & & & \\
& & & & \\
Mustralia 94 & 11.2 & 12.2 & 37.8 & 9.3 \\
Canada 94 & 10.8 & 12.3 & 38.3 & 8.6 \\
Finland 95 & 2.7 & 2.7 & 5.1 & 3.7 \\
France 94 & 6.1 & 6.5 & 12.9 & 5.5 \\
Germany 94 & 11.3 & 13.7 & 40.9 & 9.5 \\
Holland 94 & 6.9 & 7.6 & 20.4 & 6.0 \\
Sweden 95 & 2.1 & 1.8 & 4.4 & 3.7 \\
UK 95 & 10.4 & 14.2 & 31.6 & 9.2 \\
US 94 & 14.9 & 18.2 & 45.4 & 10.7 \\
\hline
\end{tabular}

${ }^{a}$ Poverty status indicates that one's disposable family income is less than $50 \%$ of the median disposable family income in one's country. 
Table 2: Results of A Logistic Regression

Decomposition ${ }^{\text {a }}$ Showing the Percentage by

Which Other Countries' Lower Rates of of Single

Motherhood Would Reduce US Women's

Poverty Rates

$\begin{array}{lr}\text { Australia } & 13.9 \\ \text { Canada } & 11.1 \\ \text { Finland } & 13.1 \\ \text { France } & 1.4 \\ \text { Germany } & 13.8 \\ \text { Holland } & 15.3 \\ \text { Sweden } & 6.3 \\ \text { UK } & 5.3\end{array}$

${ }^{\mathrm{a}}$ The logistic regression decompositions create hypothetical poverty rates that U.S. women would have if they had the lower rate of single motherhood found in the nations above. The numbers presented here show to what extent these hypothetical U.S. women's poverty rates are lower than the actual poverty rate of U.S. women. 
Table 3: Employment Rates ${ }^{1}$ and Full-Time Employment Rates

\begin{tabular}{lccccccccc}
\hline & AS & CN & FI & FR & GE & NL & SW & UK & US \\
\hline Mothers & & & & & & & & & \\
$\quad$ Employed & 57.2 & 65.5 & 80.0 & 66.1 & 55.9 & 53.7 & 83.4 & 62.0 & 67.9 \\
$\quad \begin{array}{l}\text { Full-time } \\
\text { Single Mothers }\end{array}$ & 26.4 & 52.0 & $*$ & 41.2 & 23.7 & 7.7 & 30.6 & 18.0 & 51.9 \\
$\quad \begin{array}{l}\text { Employed } \\
\text { Full-time }\end{array}$ & 44.9 & 54.9 & 78.6 & 69.1 & 56.7 & 32.4 & 75.9 & 45.2 & 66.3 \\
All women & 26.5 & 49.2 & $*$ & 48.2 & 33.1 & 11.1 & 28.3 & 15.6 & 59.9 \\
$\quad$ Employed & 60.2 & 66.5 & 77.9 & 65.3 & 61.3 & 57.8 & 82.5 & 67.0 & 70.8 \\
$\quad$ Full-time & 35.4 & 55.9 & $*$ & 42.5 & 35.5 & 23.0 & 35.8 & 29.3 & 57.7 \\
All men & & & & & & & & & \\
$\quad$ Employed & 85.6 & 80.6 & 81.9 & 85.5 & 84.4 & 75.9 & 85.6 & 81.4 & 88.4 \\
$\quad$ Full-time & 81.6 & 66.5 & $*$ & 72.5 & 82.6 & 67.2 & 58.5 & 59.5 & 88.2 \\
\hline
\end{tabular}

${ }^{1}$ Employment refers to those who engage in any employment (including self-employment), fullor part-time. Full-time employment includes those who report working 35 or more hours per week.

*In the Finnish data, employment cannot be broken down into hours worked per week. 
Table 4: Poverty Rates based on Own Market Income, by Employment Status

\begin{tabular}{|c|c|c|c|c|c|c|c|c|c|c|}
\hline & & $\mathbf{A S}$ & $\mathbf{C N}$ & FI* & FR & GE & NL & SW & $\mathbf{U K}$ & US \\
\hline \multirow{4}{*}{ SINGLE MOMS } & Employed* & 57.1 & 55.7 & 37.2 & 57.3 & 59.1 & 62.4 & 45.9 & 64.7 & $\overline{54.9}$ \\
\hline & Full-time* & 32.5 & 47.8 & & 42.4 & 37.3 & 30.8 & 28.0 & 17.3 & 44.4 \\
\hline & Employed & 49.5 & 41.3 & 32.7 & 50.9 & 48.0 & 46.2 & 33.3 & 61.1 & 46.9 \\
\hline & Full-time & 26.3 & 36.8 & & 38.3 & 35.9 & 32.5 & 11.1 & 9.6 & 42.2 \\
\hline \multirow[t]{4}{*}{ ALL WOMEN: } & Employed & 42.9 & 44.7 & 30.4 & 48.8 & 41.8 & 36.1 & 30.0 & 49.5 & 43.2 \\
\hline & Full-time & 22.1 & 37.1 & & 31.7 & 21.7 & 12.0 & 15.8 & 8.3 & 32.8 \\
\hline & Employed & 24.2 & 23.5 & 28.4 & 32.9 & 16.2 & 11.9 & 16.1 & 26.4 & 23.0 \\
\hline & Full-time & 22.1 & 24.5 & & 23.7 & 15.2 & 9.6 & 10.9 & 1.9 & 21.4 \\
\hline
\end{tabular}

*Employment refers to any full- or part-time employment; full-time employment refers to 35 or more hours per week. Employment cannot be broken down into hours worked per week in the Finnish data. 
Table 5: The Percentage Reduction in Poverty Rates Due To the Receipt of Social Transfers and Tax Benefits

\begin{tabular}{lrrrrrrrrr}
\hline & AS & CN & FI & FR & GE & NL & SW & UK & US \\
\hline Mothers & 43.3 & 38.5 & 79.2 & 69.2 & 28.6 & 53.4 & 89.8 & 49.3 & 13.3 \\
Single Mothers & 44.2 & 31.4 & 86.3 & 63.7 & 28.0 & 73.2 & 89.1 & 56.9 & 14.0 \\
Women & 44.6 & 39.7 & 79.4 & 73.5 & 38.3 & 62.1 & 87.6 & 53.2 & 14.9 \\
Men & 40.0 & 39.9 & 74.7 & 70.6 & 34.5 & 58.3 & 78.2 & 48.6 & 10.8 \\
\hline
\end{tabular}


Table 6: The Extent to Which Full-Time Employment and Social Transfer/Tax Systems $\underline{\text { Reduce Mothers' And Single Mothers' Poverty Rates }}$

\begin{tabular}{|c|c|c|c|c|}
\hline & & & ne Emplo & \\
\hline & & Low & Moderate & High \\
\hline$\frac{\text { Social }}{\text { Transfers/ }}$ & Low & US & & \\
\hline Taxes: & Moderate & $\mathbf{C N}$ & $\begin{array}{c}\text { AS, GE, } \\
\text { NL }\end{array}$ & UK \\
\hline & High & FR & & SW, FI* \\
\hline & & $\begin{array}{l}\text { This ref } \\
\text { only, not } \\
\text { employm } \\
\text { ffective }\end{array}$ & $\begin{array}{l}\text { effects of } \\
\text { employm } \\
\text { - or full-tin } \\
\text { land. }\end{array}$ & $\begin{array}{l}1 \text { transfer } \\
\text { or Finlan } \\
\text { educes po }\end{array}$ \\
\hline
\end{tabular}


Appendix Table 1: The Logistic Regression of US

Women's Poverty on Selected Independent Variables

And Their Means on These Variables

\begin{tabular}{|c|c|c|c|}
\hline \multicolumn{2}{|c|}{ Coefficient } & Odds Ratio & Mean \\
\hline Intercept & -3.39 & & \\
\hline $\begin{array}{l}\text { Single female } \\
\text { parent }\end{array}$ & 2.17 & 8.74 & .137 \\
\hline $\begin{array}{l}\text { Single female } \\
\text { nonparent }\end{array}$ & 1.54 & 4.69 & .142 \\
\hline $\begin{array}{r}\text { Married female } \\
\text { parent }\end{array}$ & 0.10 & 1.11 & .439 \\
\hline Age & -0.01 & 0.99 & 41.0 \\
\hline Number of kids & 0.31 & 1.37 & 1.08 \\
\hline $\begin{array}{r}\text { Age of youngest } \\
\text { kid }\end{array}$ & -0.04 & 0.96 & 4.01 \\
\hline Ed 1 & 2.99 & 19.92 & .042 \\
\hline $\mathrm{Ed} 2 \mathrm{a}$ & 2.47 & 11.85 & .081 \\
\hline Ed $2 b$ & 1.41 & 4.08 & .347 \\
\hline Ed 3 & 0.84 & 2.32 & .288 \\
\hline
\end{tabular}

Note: Bold coefficients are significant at the $\mathrm{p}<.05$ level. Ed. 1 refers to having a primary education only; Ed 2a low-tier secondary education; Ed 2b higher-tier secondary education; Ed 3 a post-secondary education. The reference category is college degree or higher. The reference category for the marital status variable is married female non-parents. 